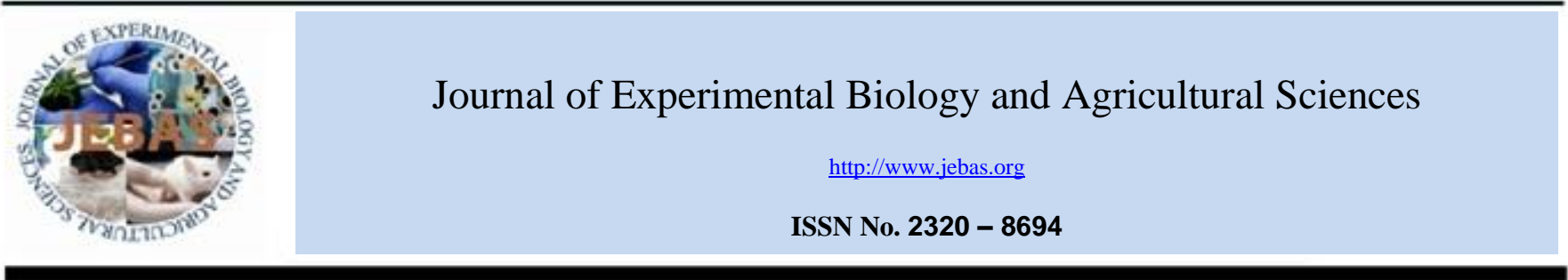

\title{
EFFECT OF LESNOV'S FERMENT SUPPLEMENTED DIET ON ISA BROWN CHICKEN MEAT PRODUCTION
}

\section{Akulina Vasilevna Popova ${ }^{1 *}$, Natalia Matveevna Chernogradskaya ${ }^{1}$, Mikhail Fedoseevich Grigoriev $^{1}$, Alexandra Ivanovna Grigorieva ${ }^{2}$, Vladimir Viktorovich Pankratov ${ }^{1}$, Victoria Kimovna Evsyukova ${ }^{1}$, Anna Ivanovna Pavlova ${ }^{1}$, Egor Denisovich Alekseev ${ }^{1}$, Svetlana Innokentievna Stepanova ${ }^{2}$}

${ }^{1}$ Yakut State Agricultural Academy, 677007, Republic of Sakha (Yakutia), Yakutsk, Sergelyakhskoye Highway, 3y km,3, Russian Federation

${ }^{2}$ North-Eastern Federal University named after M.K. Ammosov, 677013, Republic of Sakha (Yakutia), Yakutsk, Kulakovskiy St., 48, Russian Federation

Received - January 23, 2018; Revision - March 29, 2018; Accepted - June 15, 2018

Available Online - June 20, 2018

DOI: http://dx.doi.org/10.18006/2018.6(3).503.508

KEYWORDS
Yakutia
Chickens
Feeding
Feed additive
Meat production
Poultry

* Corresponding author

E-mail: grig_mf@mail.ru (Akulina Vasilevna Popova)

Peer review under responsibility of Journal of Experimental Biology and Agricultural Sciences.

Production and Hosting by Horizon Publisher India [HPI] (http://www.horizonpublisherindia.in/).

All rights reserved.

\begin{abstract}
Present study investigates the effect of Lesnov's ferment supplemented diet on meat production in ISA Brown chickens. The experiments were carried out on 28 to 44 weeks old ISA Brown chicken of Khrabraya Ptitsa LLC of Tattinskiy Ulus of the Republic of Sakha (Yakutia). For the experiment, two groups (control and experimental) were formed, each group has 200 animal units. Animal of control group fed on basic diet while animals belong to experimental group fed on the basic diet supplemented withLesnov's ferment. The control slaughter was made on the age of 40 weeks, 5 animals from each units. The preslaughter weights, slaughter weight, the weight of internal organs were taken into account. Further, organoleptic and physicochemical characteristics of meat havebeen studied. Result of study revealed that addition of the Lesnov's ferment had positive effect on the dynamics of the live weight.Thus, at the age of 44 weeks, the absolute growth in experimental group chickens was $15.1 \%$ higher than that of the control group. Further, the pre-slaughter live weight of the experimental group chickens was reported $9.6 \%$ higher than that of the control one. By total weight, the muscle tissues of the chickens fed on experimental diet have $10.9 \%$ higher than that of the herdmates. At cooking, the broth of both groups was transparent and rich but in case of animals fed on Lesnov's ferment supplemented diet broth was more contrast. Overall assessment of meat quality was 7.1 points in the
\end{abstract}

All the article published by Journal of Experimental Biology and Agricultural Sciences is licensed under a Creative Commons Attribution-NonCommercial 4.0 International License Based on a work at www.jebas.org.

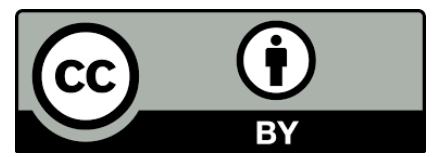


experimental group while this was only 6.8 points in the control group. Similarly,overall quality of broth for the experimental group was 7.3 and for the control group it was reported only 6.6. The content of glycogen in the chicken liver was $4,001 \mathrm{mg}$ in the experimental group while it was reported only $3,893 \mathrm{mg}$ in the control group. In the end, it was reported that feeding chickens on the ferment preparation allowed to increase the profitability of the experimental group by $7.3 \%$.

\section{Introduction}

Poultry production plays important socioeconomic roles in the economy of the developing countries. In Republic of Yakutia poultry production is an important part of routine livestock production, cash income generation and to fulfill their meat and egg demand.In case of agro-industrial complex development in the Republic of Yakutia, extreme climatical conditions became most important obstacle (Gavrilova, 1962; Grigoriev et al., 2014).In order to increasing the productivity of farm and poultry animal under harsh environmental condition of Yakutia, feed additives can be use as an alternative (Pankratov et al., 2016).

In order to increasing the biological value of poultry products, now in these days new feed additives are being used in Yakutia (Nikolaeva et al., 2015). Further, in poultry industry feed additives have been widely used as tool to increase animal performances. Now in these days, use of Lesnov's ferment as an feed additives very common in Yakutia (Lesnov \& Lesnova 2003). This Lesnov's ferment preparation is a combination of elk ruminal fluid and specific plants extract with high biological activity (Lesnov, 1998; Lesnov \& Lesnova 2002; Lesnov\&Lesnova 2003; Popova 2009).It has been well reported that that broilers fed on fermented diets have higher BW and improved feed conversion as compared to the traditional broilers feed (Brand et al., 2018).

Further, it is known that the production of agricultural poultry is characterized by live weight and meat qualities at the slaughter age, as well as the food value of meat. Poultry meat is characterized by high food value, excellent dietary and taste qualities. Low feed costs per unit of growth, early ageing, and the high quality of meat are of particular importance for the development of poultry meat production (Rogov et al., 2000). Further, chemical composition of poultry meat varies and depending on the age and breed of poultry, live weight, fatness, feeding conditions, degree, and the fattening intensity (Zhitenko, 1989).

The availably of literature on the use and effect of the Lesnov's ferment feed on meat productivity, quality of meat, food and biological value of poultry meat in Yakutia are in scarcity.Therefore, present study has been carried out to estimate the influence of the Lesnov's ferment on the meat productivity of ISA Brown chickens in the conditions of Yakutia.Further, meat quality, organoleptic and physicochemical characteristics of Brown chickens meat was also estimated in present study.

\section{Materials and Methods}

Present experiment was carried out in randomized complete block design on ISA Brown chicken crosses aged from 28 to 44 weeks on the basis of the Khrabraya Ptitsa LLC of Tattinskiy Ulus of the Republic of Sakha (Yakutia). Studied organisms were devided in two groups (control and experimental), each group have 200 animal units. In addition to the basic commercial diet, the experimental group diet is supplemented by the Lesnov's ferment. For comparison, each month, birds were weighed by random sampling of 5 animals from each group.

In present study, full-feed mixed fodders were imported from the Novosibirsk feed mill and have been used to feed ISA brown chickens. The main diet was PK-1 fodder and sprouted grain (made by Combi-Korm Russia). the composition of the feed is presented in Table 1. This economic diet corresponded to the

Table 1Characteristics of mixed feed PK-1 for laying hens

\begin{tabular}{|lc|}
\hline \multicolumn{1}{|c|}{ Composition } & Intherecipe \\
\hline Wheat & $62.5 \%$ \\
\hline Boneflour & $4.0 \%$ \\
\hline Sunfloweroil & $2.3 \%$ \\
\hline Yeast & $2.5 \%$ \\
\hline Bicarbonateofsoda & $0.070 \%$ \\
\hline Salt & $0.101 \%$ \\
\hline Tricalcium phosphate & $1.95 \%$ \\
\hline Limestone flour & $7.50 \%$ \\
\hline Sun flower meal & $17.5 \%$ \\
\hline L-threonine (98\%) & $0.118 \%$ \\
\hline L- lysine monochlorohydrate & $0.301 \%$ \\
\hline DL- methionine (98.5\%) & $0.100 \%$ \\
\hline Choline chloride B4 & $0.06 \%$ \\
\hline
\end{tabular}


biological needs of birds and was compiled taking into accountas per the standard recommendations (Kalashnikov et al., 2003; Yegorov, 2007). The feeding was performed twice a day.

The consumption of the Lesnov's ferment depends on the feed volume, for example, $5 \mathrm{~g}$ of dry raw material is sufficient for 1 ton of powder (Lesnov \& Lesnova, 2002; Lesnov \& Lesnova, 2003; Lesnov \& Lesnova, 2004). Experimental animal fed the Lesnov's ferment once a day. The feed eatability in the experimental groups was $97.5 \%$ versus $95 \%$ in the control one.

Five animals from each group were slaughtered at the age of 40 weeks to study the process of nutrients' accumulation in the body of chickens. At the same time the preslaughter weight, slaughter weight, and the weight of internal organs were taken into account with the help of laboratory balance. Sampling and study of poultry meat were performed as per the guide line of GOST 7702.2.0-95 and GOST 7702.1-74. Further, for the chemical analysis of meat, existing standards protocol of GOST 9793-74, GOST 23042-86 and GOST 25011-81 were used in present study. Mineral composition of poultry meat was determined by using an atomic absorption spectrophotometer (Perkin Elmer device, USA). The organoleptic parameters were studied as per the guide line of GOST 7702.0-74.

The samples had been taken from the hip muscles, and the extracts were prepared for the physicochemical and biochemical studies. Hydrogen ion concentration $(\mathrm{pH})$, amino-ammonia nitrogen, volatile fatty acid levels, peroxidase and primary protein decay products in broth, acid and peroxide number of fat were determined by the method given by Rogov (2000).

The experiment data allowed defining the amount of revenue generated from the sale of adult chicken meat, thus resulting in determining the economic efficiency of using the ferment preparation in the poultry production. The digital material that had been obtained in the experiments was processed using the Microsoft Excel computer program and biometrically using the method of Plokhinsky (1969), where the estimated indicators as the average value and its error are denoted by $\mathrm{M} \pm \mathrm{m}$, with the criteria of reliability for Student's t-distribution.

\section{Results and Discussion}

Effect of Lesnov's ferment supplemented diet on live weight of the ISA Brown laying chickens has been given in Table 2 .

Result of live weight gain was not significantly different which suggested that Lesnov's ferment did not have any significant effect on the weight gain of ISA Brown laying chickens. At the age of 36 weeks, the absolute growth in the chickens of the experimental group was $336 \mathrm{~g}$ compared to $224 \mathrm{~g}$ in the control group. By the end of study period (44 weeks), the absolute growth in the chickens of the experimental group was $791 \mathrm{~g}$, which was $15.1 \%$ higher than that in the control group $(\mathrm{P}>0.95)$.

The chickens were slaughtered to assess meat production at the age of 40 weeks. Indicators of meat production of chickens and morphological composition of carcasses are presented in Table 3.

Table 2 Dynamics of the live weight of the ISA Brown chickens $(\mathrm{M} \pm \mathrm{m})$

\begin{tabular}{|c|c|c|c|c|c|c|}
\hline \multirow[b]{2}{*}{ Age } & \multicolumn{2}{|c|}{ Weight (g) } & \multicolumn{2}{|c|}{ Absolute growth (g) } & \multicolumn{2}{|c|}{ Growth over control (g) } \\
\hline & $\begin{array}{c}\text { Control Diet } \\
(\mathrm{n}=5)\end{array}$ & $\begin{array}{l}\text { Experimenta 1Diet } \\
(\mathrm{n}=5)\end{array}$ & $\begin{array}{c}\text { Control Diet } \\
(\mathrm{n}=5)\end{array}$ & $\begin{array}{c}\text { Experimental Diet } \\
(\mathrm{n}=5)\end{array}$ & $\begin{array}{c}\text { Control Diet } \\
(\mathrm{n}=5)\end{array}$ & $\begin{array}{c}\text { Experimental Diet } \\
(\mathrm{n}=5)\end{array}$ \\
\hline 28 weeks & $1664 \pm 10.78$ & $1679 \pm 9.84$ & - & - & - & - \\
\hline 36 weeks & $1881 \pm 18.81$ & $2015 \pm 18.72 *$ & 224 & 336 & 672 & 791 \\
\hline 44 weeks & $2336 \pm 19.06$ & $2470 \pm 17.22 * *$ & 100 & 106.7 & 100 & 105.7 \\
\hline
\end{tabular}

Table 3 Meat production and morphological composition of chicken carcasses $(\mathrm{M} \pm \mathrm{m})$

\begin{tabular}{|c|cc|}
\hline Indicators & & Groups \\
\hline Preslaughter weight $(\mathrm{g})$ & Control $(\mathrm{n}=5)$ & Experimental $(\mathrm{n}=5)$ \\
\hline Weight of pan-ready carcass $(\mathrm{g})$ & $2,336 \pm 19.06$ & $2,470 \pm 17.22^{* *}$ \\
\hline Slaughter yield $(\%)$ & $1,709.9 \pm 11.35$ & $1,812.9 \pm 9.89^{* *}$ \\
\hline Edible parts $(\mathrm{g})$ & 73.2 & 73.4 \\
\hline Edible parts in \% to pre-slaughter weight & $1,343.2 \pm 8.33$ & 60.7 \\
\hline Edible parts in \% to the carcass weight & 57.5 & 82.7 \\
\hline Muscle mass (g) & 78.5 & $983.06 \pm 4.45^{* *}$ \\
\hline including chest muscles $(\mathrm{g})$ & $876 \pm 6.17$ & $305.70 \pm 3.86$ \\
\hline Muscle yield to preslaughter weight $(\%)$ & $268.3 \pm 4.67$ & 39.8 \\
\hline Muscle yield to the carcass weight $(\%)$ & 37.5 & 54.2 \\
\hline
\end{tabular}

Note: $* \mathrm{P}>0.95 ; * * \mathrm{P}>0.99$

Journal of Experimental Biology and Agricultural Sciences

http://www.jebas.org 
Result of study revealed that the pre-slaughter live weight of chickens kept on the experimental diet was $9.6 \%$ higher than that in the control group. At the same time, the weight of pan-ready carcass of chickens in the first group (ferment) was $1,812.9 \mathrm{~g}$ while chickens fed on the normal diet, the weight of pan-ready carcass was1,709.9 g. Further, chicken carcasses from the experimental group were $5.7 \%$ heavier than that of the analogues $(\mathrm{P}>0.99)$.

According to the total weight of muscle tissue, chickens from the experimental group produces $10.9 \%$ more than their peers $(\mathrm{P}>$ 0.99). At the same time, the largest amount of edible weight was $13.2 \%$ higher than the control $(\mathrm{P}>0.95)$. Consequently, the ferment preparation facilitated the production of a heavier carcass with the largest amount of edible muscle tissue.

The chemical composition of poultry is one of the most objective indicators of the nutritional value. The change in the chemical composition of meat is of great importance, it help to judge the physiological ageing, energy value, peculiarities of the conversion of nutrients and the energy of fodder into meat production. The results of chicken chest muscles chemical composition are presented in Table 4.

Like other parameters, weight of chest muscles also not significantly differs between two groups. Although, the chickens in the experimental group have higher fat content $(1.13 \%)$ but it was not significantly differ from the control one $(\mathrm{P}>0.99)$. At the same time, the protein content was reduced by $1.7 \%(\mathrm{P}>0.95)$. Apparently, the increase in the body weight of chickens from the experimental group occurs due to the largest deposition of fat tissue in the body.

Subcutaneous and internal fat tissue of carcasses from the control group was slightly yellow while it was bright yellowish in the experiment group. The muscles on the incision were slightly moist and did not leave stains on the filter paper. When cooking, the broth of both groups was transparent and rich, but more contrast indicator was observed in the broth of experimental group (Table 5).

According to the nine-point system, the overall assessment of meat quality was as according to GOST 7702.0-74 nine point scale. Result of study revealed that total score was 7.1 points for the experimental group while it was reported that 6.8 points for the control group.While, overall broth quality was 7.3 and 6.6 points for experimental and control group respectively.

Therefore, the feeding of chickens with Lesnov's ferment improved the organoleptic characteristics of meat (appearance, aroma, taste) and broth quality (appearance, aroma, richness), and also increased the overall assessment of meat and broth quality.

The ageing of meat supposes a complex set of processes. The ageing stage of poultry meat (stiffness, softening and deep autolysis) begins and ends earlier (after 12-24 h) than in other animal species (Table 6).
Table 4 Chemical composition and quality of poultry $(\mathrm{M} \pm \mathrm{m})$

\begin{tabular}{|c|cc|}
\hline \multirow{2}{*}{ Indicators } & \multicolumn{2}{|c|}{ Groups } \\
& Control (n=5) & Experimental (n=5) \\
\hline Water (\%) & $67.7 \pm 0.737$ & $68.2 \pm 0.065$ \\
\hline Protein (\%) & $25.9 \pm 0.666$ & $24.2 \pm 0.159^{*}$ \\
\hline Fat (\%) & $4.84 \pm 0.181$ & $5.97 \pm 0.020^{* *}$ \\
\hline Ash (\%) & $0.95 \pm 0.087$ & $0.95 \pm 0.029$ \\
\hline
\end{tabular}

Note: $* \mathrm{P}>0.95 ; * * \mathrm{P}>0.99$

Table 5 The results of tasting chicken broth and boiled meat, an organoleptic scale rated at points

\begin{tabular}{|ccc|}
\hline & Control (n=5) & Experimental (n=5) \\
\hline Color & 6.8 & 7.3 \\
\hline Taste & 7.0 & 7.6 \\
\hline Smell & 6.7 & 7.3 \\
\hline Strength & 6.3 & 7.0 \\
\hline Richness & 6.5 & 7.2 \\
\hline Total score & 6.6 & 7.3 \\
\hline$\%$ of total score & 73.3 & 81.1 \\
\hline & Cooked meat & 8.0 \\
\hline Taste and smell & 7.3 & 5.9 \\
\hline Hardness & 6.3 & 7.4 \\
\hline Juiciness & 7.0 & 7.1 \\
\hline Total score & 6.8 & 78.8 \\
\hline$\%$ of total score & 75.5 & \\
\hline
\end{tabular}

Table 6 Physicochemical parameters of chicken carcasses

\begin{tabular}{|ccc|}
\hline \multirow{2}{*}{ Indicators } & \multicolumn{2}{c|}{ Groups } \\
\cline { 2 - 3 } Meat $\mathrm{pH}$ & Control & Experimental \\
\hline $\begin{array}{c}\text { Amino-ammonia nitrogen, } \\
\text { mg. }\end{array}$ & 1.09 & $5.6-5.7$ \\
\hline Volatile fatty acids, mg. & 4.02 & 3.02 \\
\hline Reaction to peroxidase & positive & positive \\
\hline $\begin{array}{c}\text { Reaction to the primary } \\
\text { breakdown of proteins }\end{array}$ & negative & negative \\
\hline
\end{tabular}


The $\mathrm{pH}$ value after a 24-hour ageing in the meat of chickens that had been fed with the Lesnov's ferment was in the range of 5.65.7, and in both chickens that had not administered the Lesnov's ferment, it was reported 5.8-6.0.The reaction to peroxidase in all samples had confirmed that the meat of the experimental chickens met the criteria of the control ones.

The content of amino-ammonia nitrogen in the meat of chickens, which had received the ferment diet was slightly less $(1.02 \mathrm{mg}$.) than in the control group (1.09 mg.). Further, the results of the reaction of the meat broth of both groups of chicken with copper sulphate showed a negative result.

Processes of meat ageing are mainly associated with glycolysis, the glycogen in the muscles and liver of chickens was also determined in present study. The content of glycogen in the liver of chicken fed with the ferment was $4,001 \mathrm{mg}$ while in the chicken fed on normal diet, this value was $3,893 \mathrm{mg}$. On average, the level of glycogen in the liver in the first case was $198 \mathrm{mg}$ higher than in the liver of chicken of the control group (Table 7).

The glycogen content in the muscles of the chickens in the experimental group ranged from 826 to $2,582 \mathrm{mg}$ while in case of control group this value ranged from 491 to $2,146 \mathrm{mg}$. On average, it was 335-436 mg.higher in the experimental chickens as compared to control.

The determination of the number of volatile fatty acids indicated the freshness of meat in both groups. Peroxide and acid number were also determined in fat. The study of internal fat was conducted to determine the effect of ferment on the indicators of its good quality.

In the modern conditions of market relations' development, the main criterion for evaluating a particular technology or systems of meat production is the economic efficiency indicators that determine the choice of the priority direction and the option of the animals' growing technology.Calculations of the ferment effectiveness for the cultivation of rearing flocks are presented in Table 8 .

In the experimental group of chicken'stotal, 1,940 rubles additional income was generated by sellingmeat at prices of 2009. At the same time, the cost of $1 \mathrm{~kg}$ of meat decreased by 5.0 rubles (difference $6.3 \%$ ). In the control group of chickens kept on an economic diet, the level of profitability of poultry production was $7.7 \%$. Feeding of the ferment preparation allowed increasing the profitability of the experimental group by $7.3 \%$ and amounted to $15 \%$.

Comparison with similar studies revealed that experimental diet supplemented with Lesnov shows superiority over the traditional
Table 7 The content of glycogen in the liver and muscles of experimental chickens $(\mathrm{mg})$

\begin{tabular}{|ccc|}
\hline & \multicolumn{2}{c|}{ Groups } \\
Indicators & Control $(\mathrm{n}=5)$ & Experimental $(\mathrm{n}=5)$ \\
\hline Liver & 3,893 & 4,001 \\
\hline Muscles & $491-2,146$ & $826-2,582$ \\
\hline
\end{tabular}

Table 8 The efficiency of feeding a feed additive for the production of poultry

\begin{tabular}{|l|cc|}
\hline \multicolumn{1}{|c|}{ Indicators } & \multicolumn{2}{c|}{ Groups } \\
& Control & Experimental \\
\hline Preservation of groups (\%) & 92.0 & 96.0 \\
\hline Cost of gross meat production (in rubles) & 26,743 & 29,580 \\
\hline Selling price of 1 kg of poultry (in rubles) & 85.0 & 85.0 \\
\hline Total costs for meat production (in rubles) & $24,819.0$ & $25,716.0$ \\
\hline Cost of 1 kg of meat (in rubles) & 78.9 & 73.9 \\
\hline Total profit received (in rubles) & $1,924.0$ & $3,864.0$ \\
\hline Profitability (\%) & 7.7 & 15.0 \\
\hline
\end{tabular}

mixed fodder (Dadashko \& Kuznecova, 2003). Similar results were reported by Volkova (2006) when they tried popular enzyme preparation Avizim 1200.

\section{Conclusion}

At the end of the study (at 44 weeks of age), the growth in the chickens of the experimental group was $15.1 \%$ higher $(\mathrm{P}>0.95)$ than the control diet animals. They produced heavier carcasses (5.7\%), muscle tissue (10.9\%), edible mass (13.2\%), and fatty tissue $(2.49 \%)(\mathrm{P}>0.99)$.In case of chest muscle characteristics, chickens of the experimental group have higher fat content $(1.12 \%)$ and lower protein content $(1.6 \%)$ compared to the control. Like other characteristics, feeding of chickens with the Lesnov's ferment improved the organoleptic characteristics of meat (appearance, aroma, taste) and broth quality (appearance, aroma, richness), and also increased the overall assessment of meat and broth quality. Further, feeding on Lesnov's ferment was also reported cost effective and beneficial under the climatic conditions of Yakutia. This study opened great possibilities of using the ferment preparation in poultry and processing enterprises. 


\section{References}

Brand TS, Engelbrecht JA, Van der Merwe J, Hoffman LC (2018) Feed preference of grower ostriches consuming diets differing in Lupinusangustifolius inclusion levels. South African Journal of Animal Science 48: 170-185.

Dadashko VV, Kuznecova TS (2003) Mixed fodders with various grain bases. HAH Bulletin Belarus 1: 58-63.

Gavrilova MK (1962) Climate of Central Yakutia (In Russian). Yakutsk Publishing House, Yakutsk.

GOST 23042-86. Meat and meat products. Methods for determining fat content. [Electronic resource]. Available on http://stroysvoimirukami.ru/gost-23042-86/, accessed on 17February 2018.

GOST 25011-81. Meat and meat products. Protein determination methods. [Electronic resource]. Available on http://internetlaw.ru/gosts/gost/22400/, accessed on 17February 2018.

GOST 7702.0-74. Poultry meat. Sampling methods. Organoleptic methods of quality assessment. [Electronic resource]. Available on http://internet-law.ru/gosts/gost/46566/, accessed on 17February 2018.

GOST 7702.1-74. Poultry meat. Methods of chemical and microscopic analysis of the freshness of meat. [Electronic resource]. Available on http://www.internetlaw.ru/gosts/gost/16995/, accessed on 17February 2018.

GOST 7702.2.0-95. Poultry meat, byproducts and semifinished products of poultry. Methods of sampling for microbiological studies. [Electronic resource]. Available on http://internetlaw.ru/gosts/gost/9287/, accessed on 17February 2018.

GOST 9793-74. Meatproducts. Methods for determining moisture. [Electronic resource]. Available on http://www.internetlaw.ru/gosts/gost/36372, accessed on 17February 2018.

Grigoriev MF, Chernogradskaya NM,Vinokurov NV (2014) The raising adaptation abilities of beef cattle in conditions of Yakutia. V mire nauchnykhotkrytiy. DOI: 10.12731/wsd-2014-4.1-12.

Kalashnikov AP, Fisin VI, Scheglov VV, Kleymenov NI (2003) Norms and rations of feeding of farm animals (In Russian).Rosselkhozakademiya, Moscow.
Lesnov AP (1998) Lesnov's ferment, one-time, Pat. 200/019492, Russian Federation.

Lesnov AP, Lesnova OP (2002) A multipurpose preparation for obtaining high-protein food (In Russian). Sel'skokhozyaystvennyyoptovik 6: 8-9.

Lesnov AP, Lesnova OP (2003) Lesnov's ferment - a preparation for obtaining high-protein feed (In Russian). Agrarnayanauka 2: 55-56.

Lesnov AP, Lesnova OP (2004) New biotechnologies in feed production. Sel'skokhozyaystvennyyoptovik 9: 65-66.

Nikolaeva NA, Pankratov VV, Chernogradskaya NM, Grigoriev MF (2015) The use of feed additives in the diet of cows and young cattle in Yakutia. Biosciences Biotechnology Research Asia 12: 1651-1657.

Pankratov VV, Chernogradskaya NM, Popova AV, Grigorev MF (2016) Hongurin's appliance at the growing stage for the replecements of cattle of Simmentalsky breed in Yakutia. The International Scientific Journal 2: 57-61.

Plokhinskiy NA (1969)Biometrics manual for livestock experts. Kolos, Moscow.

Popova, AV (2009) Growth, development and meat production of chickens of different crosses when feeding with Lesnov's ferment. Yakutsk.

Rogov IA, Zabashta AG, Kazyulin GP (2000) Chemistry of food. Book 1: Proteins: structure, functions, role in nutrition. Kolos, Moscow.

Rogov IA (2000) General technology of meat and meat products (In Russian). Kolos, Moscow.

Volkova AV (2006) The use of the enzyme preparation Avizim 1200 in the composition of feed mixtures during the cultivation of goslings-broilers. Omsk.

Yegorov I (2007) Feeding poultry of egg crosses (In Russian). Ptitsevodstvo 7: 9-11.

Zhitenko PV (1989) Veterinary and sanitary examination of livestock products: Reference book (In Russian). Agropromizdat, Moscow. 